\title{
eCommons@AKU
}

THE AGA KHAN UNIVERSITY

Institute for Educational Development

Institute for Educational Development, Karachi

January 2006

\section{International perspectives on citizenship, education and religious diversity}

Sarfaroz Niyozov

Aga Khan University, sarfaroz.niyozov@aku.edu

Follow this and additional works at: http://ecommons.aku.edu/pakistan_ied_pdck

Part of the Bilingual, Multilingual, and Multicultural Education Commons, Educational Assessment, Evaluation, and Research Commons, Other Education Commons, Other Educational Administration and Supervision Commons, and the Other Teacher Education and Professional Development Commons

\section{Recommended Citation}

Niyozov, S. (2006). Book review [Review of the book International perspectives on citizenship, education and religious diversity, by R. Jackson]. Citizenship Teaching and Learning, 2(1), 91-92. 


\section{International perspectives on citizenship, education and religious diversity}

Edited by Robert Jackson. Published 2003 by Routledge Falmer, London and New York.

The last quarter of the 20th century has witnessed the proliferation within the public realm of religious discourses contested by globalization's intense flow of peoples, ideas, technologies, and goods; modernity's attachment to scientific and rationalist certainties; and late modernity's celebration of uncertainty, multiplicity, difference, and particularity. Against this backdrop, the book's questions such as "can people from different cultural, political or religious backgrounds live together in peace?" on page 204 are authentic. Rich in content and sophisticated in language, this well-structured edition of 11 chapters about the complex relationship between religious and citizenship education is divided into an analytical and a practical section.

Jackson's introduction, followed by the volume's first section, portray the various philosophical and historical perspectives on the concepts of citizenship, religion, and identity. These discussions highlight both the tensions and the opportunities they create for education about global justice. For example, can religion and religious education nourish both societal cohesion and pluralism, if "multicultural societies are to be conceived not as a patchwork of five or ten fixed cultural identities, but as an elastic web of cross-cutting and always mutually 
situational identifications" (p. 11); Should religion and religious education be part of public schooling, remain confined to private, faith-based separate schools, or be provided outside school? Issues like these are central to the volume.

Unlike David Hargreaves (1994), this volume's authors endorse religious education's inclusion in public schools as "important for development of intercultural communication, tolerance and peace..." (p. 205). They warn that leaving religious education to others has proved to be too perilous. More so, as an important aspect of students' background and as a complex phenomenon, religion can be engaged to enrich citizenship education. It can reinforce the humanistic values and ethics and create balanced, informed, and tolerant citizens who are neither embarrassed to meet the 'other' in their workplace, nor ashamed of ignorance while travelling to and living amongst people from different countries and cultures. As one Muslim mother articulates "A school that refrains from interreligious education is evading its social responsibility. I do not want my child to be 'foreignized'. I want her to live in calm and in diversity of colour." (p. 206).

Grounded in culturalist, feminist, and South-African contexts, Chidester, Tobler, and Steyn in their chapters illustrate how modern concepts of citizenship and religion (e.g., Marshall's (1950)) with Eurocentric and masculine agendas are becoming irrelevant. They propose to reconstruct these concepts to develop more inclusive, just, and empowered citizenship and society at local, national, transcultural, and global levels.

Leganger-Kronstad's review of innovative practices in Scandinavia and Chidester's critique of the 'world religions' course elsewhere are accompanied by an array of alternative pedagogies described by Ipgarve, Leganger-Krongstad, Weisse and Blaytock. These innovative pedagogies and classroom and community-related projects embrace experiential ethnography and personal interpretation, dialogue and diapractice, critical inquiry and research, reflection and debate, and open mindedness and tolerance.

Although the volume included an entire section dealing with practical issues, I wish the volume had included more detail about how controversial issues and extremist views are handled; how students, parents, and clerics react to these innovations; whether the learning materials represent religions pluralistically; how teachers cope with forces of cultural clashes and divisions; how the 'incompatibilities' within and between various religious doctrines and practices, as well as between religious, secular and atheist worldviews are overcome. Finally, while the emphasis on Islam is understandable given recent events, the volume would have been more balanced by more attention to other religions and the inclusion of more internationally diverse scholarship. These additions could help this otherwise wonderful book to provide teachers, teacher educators, and proponents of interfaith and intercultural dialogue with richer portrayals and more realistic hopes to draw from in enriching their practice. I highly recommend the volume to all those interested in creating a more inclusive and just world.

\section{References}

HARGREAVES, D. (1994). The mosaic of learning: schools and teachers for the next century. Demos paper 8. London: Demos.

Marshall, P. J. (1950). Citizenship and social class. Cambridge: Cambridge University Press.

Reviewer: Dr. Sarfaroz Niyozov, Ontario Institute for Studies in Education, University of Toronto, Toronto, Canada. Email: sniyozov@oise.utoronto.ca 